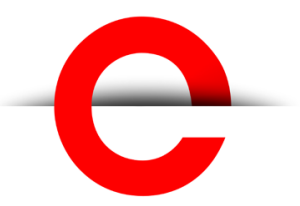

U T S

e PRES S
PORTAL Journal of

Multidisciplinary

International Studies

Vol. 13, No. 2

July 2016

Designing Futures in

Indonesia, Curated Works Special Issue, Curated by Alexandra Crosby.

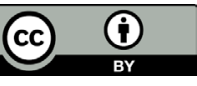

C 2016 by Alexandra Crosby. This is an Open Access article distributed under the terms of the Creative Commons Attribution 4.0 Unported (CC BY 4.0) License (https:// creativecommons.org/ licenses/by/4.0/), allowing third parties to copy and redistribute the material in any medium or format and to remix, transform, and build upon the material for any purpose, even commercially, provided the original work is properly cited and states its license.

Citation: Crosby, A. 2016. Designing Futures in Indonesia. PORTAL Journal of Multidisciplinary International Studies, 13:2, 1-6. http://dx.doi. org/10.5130/portal.v13i2.5065

ISSN 1449-2490 | Published by UTS ePRESS | http://portal. epress.lib.uts.edu.au
CURATED WORK

\section{Designing Futures in Indonesia}

\section{Alexandra Crosby}

Corresponding author: Alexandra Crosby, School of Design, Faculty of Design, Architecture and Building, University of Technology Sydney, PO Box 123, Broadway NSW 2007, Australia alexandra.crosbylauts.edu.au

DOI: http://dx.doi.org/10.5130/portal.v13i2.5065

Article History: Received 20/06/2016; Revised 27/06/2016; Accepted 11/07/2016;

Published 09/08/2016

\section{Abstract}

Design is a wide reaching and unruly idea, often associated with seamless global mobility, ubiquitous consumerism, elite urban tastes, and fast paced economic growth. But design is also increasingly understood to be operating at edges, as a necessary response to the ethical and political challenges of advanced global capitalism. Design is both the problem and the solution, and effects everything. As Tony Fry writes 'Design-the designer and designed objects, images, systems and things-shapes the form, operation, appearance and perceptions of the material world we occupy.'

This curated issue takes as its departure point Fry's notion that design broadly shapes the world we occupy. To ask what happens when the world we occupy is not conceived simply in terms of local issues and solutions, but rather as a set of shared concerns that are localised and play out through global flows. To do so this issue presents ten contributions from Indonesia.

\section{Keywords}

Indonesia; design; desain; local-glocal; design edges; global flows; design thinking 
Design is a wide reaching and unruly idea, often associated with seamless global mobility, ubiquitous consumerism, elite urban tastes, and fast paced economic growth. But design is also increasingly understood to be operating at edges, as a necessary response to the ethical and political challenges of advanced global capitalism. Design is both the problem and the solution, and it effects everything. As Tony Fry writes 'Design - the designer and designed objects, images, systems and things — shapes the form, operation, appearance and perceptions of the material world we occupy' (2009: 3).

This curated special issue of Portal takes as its departure point Fry's notion that design broadly shapes the world we occupy. The special issue asks what happens when the world we occupy is not conceived simply in terms of local issues and solutions, but rather as a set of shared concerns that are localised and play out through global flows. Attending to that question, this curated issue presents ten contributions from Indonesia.

In Indonesia, where the arrival of design is inseparable from colonisation, there are tensions between the complexity of design as a 'world shaping force' (Fry 2009: 3) and the way it manifests in local contexts, creating a sense of place, 'which includes a consciousness of its links with the wider world, which integrates in a positive way the global and the local' (Massey 1991: 7). While some design circulates globally-for example we use the same software in Jakarta and Sydney-there is also design that is produced by and reproduces place (for example where the climate is just right to grow a particular type of teak wood necessary for a particular kind of house), or at just one time, (when designers' paths cross through one project and lead to collaboration on another). Moreover not all design produces ease and convenience, and not all design solves problems. Some designers make the seams or joins of their work visible, or they leave something unfinished for the next person to take up. Some design processes go so slowly that they seem to reverse the logic of production. They operate only at small scales. They emerge only in close communities, neither in the creative clusters of institutions, nor in the think tanks of multinational companies. These are the edges of design, operating at human scale in local contexts. At these edges we find designers in gardens and kitchens. We see a privileging of craftsmanship over financial flows and sometimes we are even able to let go of the fast, new and convenient connotations of design.

While these tensions-between design as a problem and a solution; between local and global contexts - are certainly not unique to Indonesia, they play out in highly visible and often beautiful ways because of the way the local and the global are imagined across the archipelago, in particular at the scale of the kampung (neighbourhood), and because of the rich design practices that have been invented, altered and remixed over hundreds of years of trade and colonisation.

In this second curated issue of Portal, I explore design ideas in Indonesia by asking designers to articulate their practice through visual essays of photographs and drawings. These essays pay attention to small pragmatic design acts that change how we think about Indonesia, its place in the world and its assumed trajectories of progress as a 'developing' nation. As Markussen points out, 'The design act is not a boycott, strike, protest, demonstration, or some other political act, but lends its power of resistance from being precisely a designerly way of intervening into people's lives' (2013: 38)

In this issue I draw from the recent curated issue of Portal (volume 13, number 1, January 2016) in which Ilaria Vanni uses edges as a starting point to think about ecologies of transcultural processes. In Indonesia design also produces edges at which the flows of people, knowledge and materials create unexpected and unique results, approaches to urgent global 
challenges, for instance, that are grown in gardens rather than manufactured in factories. This issue opens up a space for designers to talk about design in Indonesia as a site of transition, exchange and reflection, and this reflection speaks to the significance of design at this historical moment, a moment of intensifying urbanisation and increasing exploitation of natural resources.

One of the transcultural edges explored in this issue relates to a wider research projectthe Indonesia Australia Design Futures exchange - to map emergent design practices in Indonesia and to bring together Indonesian and Australian designers, design researchers, and design educators to work on sustainable futures by rethinking the way we design food production, housing, transport and cities, all of which reveal urgent problems that affect the entire region of Southeast Asia. Indonesia, with rich and diverse cultures of local making, from batik to instrument building, is a unique laboratory where well-established creative practices meet new technologies and alternative economies in tangible everyday ways. As Kathleen Azali and Andriew Budiman explain in their essay, 'design' and its Indonesian translation desain, are relatively new, imported words, generally understood in Indonesia through the categories of graphic, interior, and product design, that tend to divide university and college faculties.

In this curated issue I present ten works by designers living or working in Indonesia. They engage with a variety of transcultural and creative edges, as they reflect on their own design practices, or those of others, as hybrid trajectories. We join Ratna Cahaya Rina as she explores graphic design at the edge of the city $(k o t a)$ and village (desa) when the internet, pirated software and what she calls 'visual literacy' make possible a creative industry that can transform the economies of small villages. With little opportunity for up-skilling and few education prospects, typical employment for many of Java's villagers includes driving trucks and and ocek (motorbike taxi). But here, in remote Java, Ratna finds self-taught designers in high demand, juggling clients all over the world and pooling resources in their makeshift studios. In this context, while still offering only precarious employment, design in a global workplace offers an alternative future for some of Indonesia's poorest communities.

In their piece, Andriew Budiman and Kathleen Azali present another side of this story by showing that, while the development of the creative industries in Indonesia has been exciting and can lift some communities out of poverty, it has not always been accompanied by critical conversations about design. They deal with the complexity of the design scene in Surabaya by tracing the emergence of the Design It Yourself Surabaya (DIYSUB) event in their essay 'Designing a Design Conference-Festival: Reflective Notes from Surabaya.'

Tarlen Handayani builds on these ideas, explaining her own design practice as a mix of imported and local aesthetics in her essay 'Book Binding in Bandung.'Tarlen looks at the productive edge between craft and design and points to how the Indonesian setting produces challenging ambiguity around craft because of the pace at which ideas spread. She sensitively navigates between her own reliance on social media for her business and the hand rendering of her craft as a fiercely independent design practice.

Also inspired by the lack of distinction between craft and design in Indonesia, Jessica Dunn, an Australian product designer, is welcomed at the edges of Indonesia's internationally acclaimed textile industry, in her story 'Batik of Batang-A Design Story.' In her analysis of the motifs of these culturally significant fabrics, she brings attention to the human, and particularly female, stories of these design practices. This allows her to challenge the devaluing of a cottage industry with its limited scale when compared to factory production. With her beautiful portraits, Jessica reminds us that batik is a craft inseparable from being human for 
Javanese people. Exemplifying what Matthew Kiem calls 'care in use' (2011: 8), the designers of batik, made on cotton or silk cloth in organic dyes, pay careful attention to the handling of the cloth, the way it is washed, how it touches skin young and old, and the ways it is passed between humans who care for one another. Batik is also an example of what Cameron Tonkinwise (2004) calls 'beauty-in-use,' where objects mediate our experience of the world, rather than standing simply before us. Although usually batik belongs to a household in Java, it is not understood as an object for display, as a painting might be. Rather, batik mediates the way Javanese mothers hold their babies and the way Javanese elders live with their families to the end of their lives.

Away from Java, at one of the geographical edges of Indonesia-the island of Rote Ndao, in the eastern province of Nusa Tenggara Timur (West Timor)—Campbell Drake and William Kelly consider the agency and responsibility of spatial design in tourism development. William's still photographs force us to contemplate the kind of slowing down that will be necessary to make ethical design decisions in this region. As designers who understand that every decision made in designing a building has a legacy, they argue that it is only by the inclusion of community consultation and careful analysis into the design process can the ecological disasters produced by tourism in Bali be avoided in Rote Ndao.

Will Scott-Kemmis, Clare Cooper and Kirsten Bradley are the Australian designers selected to participate in the Indonesia Australia Design Futures exchange. They travelled in Central Java and Bali to exchange knowledge, share ideas and work at the edges of design's global definitions. Their approach to design evokes the words of Lenskjold, Olander, and Halse, who argue that 'some types of contemporary co-design practices embody a different form of activist agency-one that is experimentally and immanently generated only as the design project unfolds' (2015: 67). In a personal and sophisticated form of design thinking, Scott-Kemmis uses space and marks on the pages of his notebook to make connections between ideas and people in Indonesia and Australia. In his visual essay, he shows us this way of thinking, tracing how it pushes and pulls at his design training, and the edges it produces.

In her essay 'Collective Improvisation' Clare Cooper makes another critique of design discourse by considering design collaboration through the lens of improvised music, reflecting on her own career with the Splitter Orchestra and Splinter Orchestra, and the NOW Now Festival. Watching design play out in transdisciplinary ways on her exchange in Java, Cooper points to the design possibilities created when trust is prioritised over competition. In the large-scale political murals of Taring Padi, she sees an edge between silence and participation where art and design is political in its collectivity.

In her piece 'Tempe as Language-A Village Revitalisation Mini-project,' Kirsten Bradley interviews creative women who are resurrecting food design practices. Like Scott-Kemmis, Kirsten is wary of the title of designer. A founder of Milkwood permaculture, she navigates the tricky territory of first, being an expert sharing her expertise, and second, opening design to mass participation. Guy Julier cites permaculture, along with the appropriate technology movement and community architecture, as one of many examples of radical thinking in design that emerged in the 1970s (2013: 225). Making sure this radical thinking can make change in a contemporary context is central to Kirsten's work. Considering permaculture as a design practice that originated in Australia (Mollison 1978) and now circulates widely through global flows of information, local translations of permacultural ethics and principles in a Javanese village align with Bradley's ongoing work. 
Another translation of permaculture is found in Bali, with designer, artist and organic farmer Ili Farhana. In response to Indonesia's food security challenge, with more people and less arable land available, Ili teaches people to grow their own food, wherever they are, in whatever way they can. Kirsten and Ili, both social media sensations-see the Instagram accounts@milkwood permaculture and @kspejeng respectively—find inspiration in a kind of remix, between the awakening of food practices that have almost been lost to industrial agriculture and the ways participatory modes of global environmentalism are shared online. In their remix, these practices-jam making, tempe making, seed sharing and gardeningbecome political, world-making acts of design futuring.

Writing about Australian-based artist Tessa Zettel's work 'making time,' Abbey Mellik Lopez draws on Jean Beaudrillard's idea of object-time and Tony Fry's thoughts of time as a medium to describe design as 'a material practice that prefigures the future' (2013). She describes the act of preserving food as a mode of futuring, an act of making time. 'In counterpoint to the ob-ject and its refutation of duration, is the design pro-ject-a prefigurative act that initiates specific change in a situation' (2013 n. p.). When Ili makes jam from rosella calyx, grown in her garden on land reclaimed from monocropping, and also translates and shares her recipe, she is also futuring and making time, offering her time to others, rather than dividing and fracturing our worlds. Time (waktu) has many modes in Indonesia: it describes seasons, light, love, growth and decay as much as it refers to hours, minutes and seconds. As the Indonesian word for hour is 'jam,' in making jam, Ili makes more hours and in doing so, offers different understandings of design as time is improbably translated and shared.

Cindy Lin and Andrew Mooon also consider the ways our categories of time define design in their two-part essay 'Negotiating Time-Design as Historical Practice' where they present stories of repair and revaluing. In the eviction zone of Kampung Pasar Ikan (Fish Market Kampung), North Jakarta, a casualty of a contentious 40 billion USD plan to design and construct a sea wall to prevent the city from sinking, residents work together to maintain, repair and redesign their electricity supplies, and as they do so, they continue to produce stories about the place and its infrastructure. Through repair, they refuse a future of erasure and demand an acknowledgement of the complexity of place. Lin and Moon write: 'Repair encourages us to take seriously the material interstices between past and future, showing how infrastructure demonstrates a historical legacy maintained to endure and retain the old but not quite.' In Kalimantan, another outer edge of Indonesia, they interview the School of Drones (SOD), a DIY drone collective, to find out how mapping can be a collaborative act of resistance in a landscape ravaged by development.

Serendipity is a buzzword in the design industry. It happens at the edges, where different forms of creativity, or different kinds of projects meet and interact. There are many translations of this word in Indonesia, none of them quite exact: spontan, improve, beruntung. Yet this idea exists in all the design presented here-in the collaborations, observations, and small, slow interventions into living. This special curated issue seeks to map and document different forms of serendipity that are happening at the edges of design practices in Indonesia today. A focus on edges facilitates an analysis of small scale emergent issues, such as those exemplified in the ten contributions presented here. However, these emergent and localised issues - the industrialisation of farming, eviction of residents in city developments, rapid tourism development—need to be seen as intersecting with contemporary global design concerns around sustainability, resilience and place-making. Food design, batik, mural painting, DIY festivals, remix and repair practices, building and book binding, embody in 
many respects concerns about how we interact with our environment and how we use the resources available to us.

The perspective adopted in this curated issue is based on the understanding of deeply localised practices that grip with contemporary global design questions. In particular, as designers working with other designers (rather than on other designers' work) the contributors to this curated issue are able to translate across multiple scales and cultural formations to a degree that is not available to other researchers. For those of us committed to ideas of design practice that shape the world, there is a need not only for a deep understanding of our own specific contexts, but also for the critical ability to see and learn from how similar matters of concern are played out across different cultural and social formations.

\section{Acknowledgements}

The research for this special curated issue has been made possible by the Australian Department of Foreign Affairs and Trade (DFAT) Australia-Indonesia Institute.

\section{References}

Fry, T. 2009, Design Futuring. Oxford, Berg

Jackson, S. J 2014, 'Rethinking Repair,' in Media Technologies: Essays on Communication, Materiality, and Society, eds T. Gillespie, P. J. Boczkowski \& K. A. Foot. MIT Press, Massachusetts: 221-237

Julier, G. 2013, 'From Design Culture to Design Activism,' Design and Culture, vol. 5, no. 2: 215-236

Kiem, M. 2011, 'Theorising a Transformative Agenda for Craft,' Craft + Design Enquiry, issue 3, 'Sustainability in Craft and Design.' Online, available: http://craftdesignenquiry.blogspot.com.au/2013/05/ theorising-transformative-agenda-for.html [accessed 30 May 2016]

Lenskjold, T.U. Olander, S. \& Halse, J. 2015, 'Minor Design Activism: Prompting Change from Within,' Design Issues, vol. 31, no. 4: 67-78

Markussen, T. 2013, 'The Disruptive Aesthetics of Design Activism: Enacting Design Between Art and Politics,' Design Issues, vol. 29, no.1: 38-50

Mellick Lopes, A. 2013, 'Seeing Things in/as Time' [Presented at Making Time in Sydney, 23 February. Online, available: http://making-time.net/?p=411 [accessed 30 May 2016]

Mollison, B. 1978, Permaculture 1: A Perennial Agricultural System for Human Settlements. Transworld Publishers, Melbourne

Tonkinwise, C. 2003, 'Beauty-in-Use,' Design Philosophy Papers, vol. 1, no. 2: 73-82

Vanni, I., 2016, 'The Transcultural Edge.' Portal Journal of Multidisciplinary International Studies, vol. 13, no. 1. Online, available: http://epress.lib.uts.edu.au/journals/index.php/portal/issue/view/372 [accessed 30 May 2016] 